Number 1

\title{
KADAR KALSIUM DARAH PADA WANITA MENOPAUSE DI DESA SINABUN, KECAMATAN SAWAN, KABUPATEN BULELENG
}

\author{
Luh Putu Devi Kartika ${ }^{1}$, Cokorda Dewi Widhya Hana Sundari ${ }^{2}$, \\ Ida Ayu Made Sri Arjani ${ }^{3}$
}

\begin{abstract}
Background: Menopause women will get a decrease in estrogen hormones that cause decreases of blood calcium level. If the calcium level in the blood is low then the body will take calcium from the bone to perform body functions, this causes calcium levels in the bones decreased so it caused osteoporosis.

Methode: This study is a descriptive study which describes blood calcium levels in menopause women in Sinabun Village, Sawan District, Buleleng Regency. The study was conducted from February until June 2017 with a population of 186 people and sample of 30 people selected by systematic random sampling technique. Measurement of blood calcium level using NM-BAPTA method.

Result: The results showed that 17\% of respondents had low blood calcium levels and 83\% of respondents had normal blood calcium levels with an average blood calcium level is 9.20 $m g / d L$.

Conclusion: The decrease of blood calcium levels occurred in respondents of age $\geq 60$ years old, the respondents with the old menopause period $>10$ years, the respondents who work as housewife and traders, the respondents who never consumed high calcium milk, and the respondents who didn't have history of hypoparathyroidism and kidney disorders.
\end{abstract}

Keyword: blood calcium, menopause.

\section{PENDAHULUAN}

Salah satu proses penuaan yang dialami oleh wanita adalah menopause. Wanita yang telah memasuki masa menopause akan mengalami penurunan produksi hormon estrogen yang menyebabkan kadar kalsium dalam darah menurun. Apabila kadar kalsium dalam darah rendah maka tubuh akan mengambil kalsium dari tulang untuk menjalankan fungsi tubuh, hal ini menyebabkan kadar kalsium dalam tulang mengalami penurunan sehingga menimbulkan osteoporosis $^{6}$. Osteoporosis juga disebut sebagai silent disease karena penyakit ini tidak menunjukkan gejala-gejala yang spesifik, sehingga diperlukan pemeriksaan kadar kalsium darah yang hasilnya dapat digunakan untuk menunjang diagnosa osteoporosis agar dapat dilakukan pencegahan lebih awal ${ }^{7}$. Berdasarkan data dari profil desa diketahui bahwa jumlah wanita usia 50-65 tahun yang menopause adalah 186 jiwa. Berdasarkan survei yang dilakukan oleh peneliti terdapat 46 orang mengeluh nyeri pada punggung, pinggang, otot, dan sendi, selain itu masyarakat juga belum pernah melakukan pemeriksaan kadar kalsium darah. 


\section{METODE}

Jenis penelitian yang digunakan dalam penelitian adalah penelitian deskriptif yaitu untuk mendeskripsikan kadar kalsium darah pada wanita menopause di Desa Sinabun, Kecamatan Sawan, Kabupaten Buleleng. Populasi penelitian yaitu seluruh wanita menopause yang berumur 50-65 tahun sebanyak 186 orang dan besar sampel adalah 30 orang yang ditentukan berdasarkan cara systematic random sampling. Teknik pengumpulan data dilakukan dengan wawancara dan pemeriksaan laboratorium.

\section{HASIL DAN PEMBAHASAN}

a. Hasil pemeriksaan kadar kalsium darah pada wanita menopause

Berdasarkan hasil pemeriksaan laboratorium, diperoleh rata-rata kadar kalsium darah pada responden adalah sebesar 9,20 mg/dL dengan kadar kalsium
Wawancara dilakukan untuk mengetahui nama, umur, lama menopause, pekerjaan, kebiasaan dalam mengkonsumsi susu berkalsium tinggi, serta riwayat penyakit responden (hipoparatiroidisme dan kelainan ginjal). Kadar kalsium darah diukur melalui pemeriksaan laboratorium menggunakan alat Cobas C501 dengan metode 5-nitro-5' -methyl-(1,2-bis(oaminophenoxy) ethan- $N, N, N^{\prime}, N^{\prime}-$ tetraacetic acid (NM-BAPTA) di Laboratorium Klinik Prodia Singaraja.

\section{HASIL}

terendah adalah $8,00 \mathrm{mg} / \mathrm{dL}$ dan kadar kalsium tertinggi adalah 10,10 $\mathrm{mg} / \mathrm{dL}$. Kadar kalsium darah pada wanita menopause disajikan pada tabel 1 berikut ini.

Tabel 1

Kadar Kalsium Darah pada Wanita Menopause

\begin{tabular}{ccc}
\hline Kadar Kalsium Darah & Jumlah & Persentase (\%) \\
\hline Rendah & 5 & 17 \\
Normal & 25 & 83 \\
Tinggi & 0 & 0 \\
\hline Total & 30 & 100 \\
\hline
\end{tabular}

Berdasarkan tabel 1 dapat diketahui bahwa sebagian besar responden memiliki kadar kalsium darah normal yaitu sebanyak 25 orang (83\%). 
b. Kadar kalsium darah pada wanita menopause berdasarkan kelompok usia
Kadar kalsium darah pada wanita menopause berdasarkan kelompok usia disajikan pada tabel 2 berikut ini.

Tabel 2

Kadar Kalsium Darah pada Wanita Menopause Berdasarkan Kelompok Usia

\begin{tabular}{lllllllll}
\hline \multirow{2}{*}{$\begin{array}{l}\text { Kelompok } \\
\text { Usia (th) }\end{array}$} & \multicolumn{2}{l}{ Kadar Kalsium Darah $(\mathrm{mg} / \mathrm{dL})$} & \multicolumn{2}{l}{ Total } \\
\cline { 2 - 7 } & Rendah & \multicolumn{2}{l}{ Normal } & Tinggi & & \\
\cline { 2 - 7 } & $\Sigma$ & $\%$ & $\Sigma$ & $\%$ & $\Sigma$ & $\%$ & $\Sigma$ & $\%$ \\
\hline$<60$ & 0 & 0 & 24 & 80 & 0 & 0 & 24 & 80 \\
$\geq 60$ & 5 & 17 & 1 & 3 & 0 & 0 & 6 & 20 \\
\hline Total & 5 & 17 & 25 & 83 & 0 & 0 & 30 & 100 \\
\hline
\end{tabular}

Berdasarkan tabel 2 dapat diketahui bahwa, terdapat 5 responden $(17 \%)$ memiliki kadar kalsium darah rendah yang ditemukan pada kelompok usia $\geq 60$ tahun. c. Kadar kalsium darah pada wanita menopause berdasarkan lama menopause

Kadar kalsium darah pada wanita menopause berdasarkan lama menopause disajikan pada tabel 3.

Tabel 3

Kadar Kalsium Darah pada Wanita Menopause Berdasarkan Lama Menopause

\begin{tabular}{lllllllll}
\hline \multirow{2}{*}{$\begin{array}{l}\text { Lama } \\
\text { Menopause }\end{array}$} & \multicolumn{9}{l}{ Kadar Kalsium Darah (mg/dL) } & \multicolumn{3}{c}{ Total } \\
\cline { 2 - 8 } (th) & Rendah & \multicolumn{3}{l}{ Normal } & \multicolumn{3}{l}{ Tinggi } & \\
\hline & $\Sigma$ & $\%$ & $\Sigma$ & $\%$ & $\Sigma$ & $\%$ & $\Sigma$ & $\%$ \\
\hline$<5$ & 0 & 0 & 9 & 30 & 0 & 0 & 9 & 30 \\
$5-10$ & 0 & 0 & 13 & 43 & 0 & 0 & 13 & 43 \\
$>10$ & 5 & 17 & 3 & 10 & 0 & 0 & 8 & 27 \\
\hline Total & 5 & 17 & 25 & 83 & 0 & 0 & 30 & 100 \\
\hline
\end{tabular}

Berdasarkan tabel 3 dapat diketahui bahwa, terdapat 5 responden $(17 \%)$ memiliki kadar kalsium darah rendah yang ditemukan pada wanita menopause yang telah mengalami menopause selama $>10$ tahun. d. Kadar kalsium darah pada wanita menopause berdasarkan Pekerjaan

Kadar kalsium darah pada wanita menopause berdasarkan pekerjaan disajikan pada tabel 4 berikut ini. 


\begin{tabular}{ccccccccc}
\hline & \multicolumn{9}{c}{ Kadar Kalsium Darah (mg/dL) } & \multirow{2}{*}{ Total } \\
\cline { 2 - 6 } Pekerjaan & \multicolumn{2}{c}{ Rendah } & \multicolumn{2}{c}{ Normal } & \multicolumn{2}{c}{ Tinggi } & & \\
\cline { 2 - 7 } & $\Sigma$ & $\%$ & $\Sigma$ & $\%$ & $\Sigma$ & $\%$ & $\Sigma$ & $\%$ \\
\hline IRT & 3 & 10 & 5 & 16 & 0 & 0 & 8 & 26 \\
Pedagang & 2 & 7 & 2 & 7 & 0 & 0 & 4 & 14 \\
Petani & 0 & 0 & 6 & 20 & 0 & 0 & 6 & 20 \\
Buruh & 0 & 0 & 12 & 40 & 0 & 0 & 12 & 40 \\
\hline Total & 5 & 17 & 25 & 83 & 0 & 0 & 30 & 100 \\
\hline
\end{tabular}

Berdasarkan tabel 4 dapat diketahui bahwa, terdapat 3 responden $(10 \%)$ dengan pekerjaan sebagai Ibu Rumah Tangga (IRT) dan 2 responden (7\%) dengan pekerjaan sebagai pedagang yang memiliki kadar kalsium darah rendah.

e. Kadar kalsium darah pada wanita menopause berdasarkan konsumsi susu berkalsium tinggi

Tabel 5

Kadar Kalsium Darah pada Wanita Menopause Berdasarkan Konsumsi Susu Berkalsium Tinggi

\begin{tabular}{|c|c|c|c|c|c|c|c|c|}
\hline \multirow{3}{*}{$\begin{array}{c}\text { Konsumsi } \\
\text { Susu } \\
\text { Berkalsium } \\
\text { Tinggi }\end{array}$} & \multicolumn{6}{|c|}{ Kadar Kalsium Darah (mg/dL) } & \multirow{2}{*}{\multicolumn{2}{|c|}{ Total }} \\
\hline & \multicolumn{2}{|c|}{ Rendah } & \multicolumn{2}{|c|}{ Normal } & \multicolumn{2}{|c|}{ Tinggi } & & \\
\hline & $\Sigma$ & $\%$ & $\Sigma$ & $\%$ & $\Sigma$ & $\%$ & $\Sigma$ & $\%$ \\
\hline Tidak pernah & 4 & 14 & 5 & 16 & 0 & 0 & 9 & 30 \\
\hline Pernah & 1 & 3 & 20 & 67 & 0 & 0 & 21 & 70 \\
\hline Total & 5 & 17 & 25 & 83 & 0 & 0 & 30 & 100 \\
\hline
\end{tabular}

Berdasarkan tabel 5 dapat diketahui bahwa, terdapat 4 responden $(14 \%)$ tidak pernah mengonsumsi susu berkalsium tinggi dan 1 responden $(3 \%)$ pernah mengonsumsi susu berkalsium tinggi sebanyak 2-3 kali dalam seminggu yang memiliki kadar kalsium darah rendah.
Kadar kalsium darah pada wanita menopause berdasarkan konsumsi susu berkalsium tinggi disajikan pada tabel 5 berikut ini. 
Berdasarkan tabel 6 dapat diketahui bahwa, terdapat 5 responden $(17 \%)$ yang memiliki kadar kalsium darah rendah yang ditemukan pada semua responden, dimana semua responden tidak ada yang memiliki riwayat penyakit (hipoparatiroidisme dan kelainan

ginjal.

Tabel 6

Kadar Kalsium Darah pada Wanita Menopause Berdasarkan Riwayat Penyakit (Hipoparatiroidisme dan Kelainan Ginjal)

\begin{tabular}{|c|c|c|c|c|c|c|c|c|}
\hline \multirow{3}{*}{$\begin{array}{l}\text { Riwayat Penyakit } \\
\text { (Hipoparatiroidisme } \\
\text { dan Kelainan Ginjal) }\end{array}$} & \multicolumn{6}{|c|}{ Kadar Kalsium Darah (mg/dL) } & \multirow{2}{*}{\multicolumn{2}{|c|}{ Total }} \\
\hline & \multicolumn{2}{|c|}{ Rendah } & \multicolumn{2}{|c|}{ Normal } & \multicolumn{2}{|c|}{ Tinggi } & & \\
\hline & $\Sigma$ & $\%$ & $\Sigma$ & $\%$ & $\Sigma$ & $\%$ & $\Sigma$ & $\%$ \\
\hline Tidak ada & 5 & 17 & 25 & 83 & 0 & 0 & 30 & 100 \\
\hline Ada & 0 & 0 & 0 & 0 & 0 & 0 & 0 & 0 \\
\hline Total & 5 & 17 & 25 & 83 & 0 & 0 & 30 & 100 \\
\hline
\end{tabular}

\section{PEMBAHASAN}

\section{Kadar kalsium darah pada wanita menopause}

Rata-rata dari seluruh hasil pemeriksaan kadar kalsium darah pada wanita menopause adalah 9,20 $\mathrm{mg} / \mathrm{dL}$ yang tergolong kategori normal. Hasil penelitian pada tabel 8 menunjukkan bahwa 17\% responden memiliki kadar kalsium darah rendah, $83 \%$ responden memiliki kadar kalsium darah normal, dan tidak ada responden memiliki kadar kalsium darah tinggi. Hal ini menggambarkan bahwa lebih banyak wanita menopause memiliki kadar kalsium darah normal. Hasil ini sejalan dengan penelitian dari Dewi (2014) di Nanjar Binoh Kaja, Desa Ubung Kaja, Kecamatan
Denpasar Utara, dimana dari 34 responden yang diteliti, 30 responden $(88,24 \%)$ memiliki kadar kalsium darah normal ${ }^{1}$. Selain itu hasil penelitian Syahputra (2016) di Panti Werdha Damai Manado juga menunjukkan sebagian besar wanita menopause memiliki kadar kalsium normal, dimana dari 30 responden terdapat 24 responden $(80 \%)$ yang memiliki kadar kalsium normal ${ }^{10}$.

\section{Kadar kalsium darah pada wanita} menopause berdasarkan kelompok usia

Hasil analisis terhadap kadar kalsium darah dari 30 responden diperoleh kadar kalsium darah terendah adalah sebesar 8,0 mg/dL yang ditemukan $\mathrm{p} 72$ 
responden dengan usia 65 tahun, sedangkan kadar kalsium darah tertinggi namun masih dalam batas normal, yaitu sebesar 10,10 mg/dL ditemukan pada responden dengan usia 52 dan 53 tahun. Hasil ini sejalan dengan penelitian Syahputra (2016), di Panti Werdha Damai Manado yang menunjukkan penurunan kadar kalsium darah terjadi pada wanita menopause yang berusia $\geq 65$ tahun $^{10}$, dan hasil penelitian Minropa (2013) juga menunjukkan penurunan kadar kalsium darah terjadi pada wanita menopause yang berusia $\geq 55$ tahun. Hasil ini menggambarkan bahwa semakin tinggi usia maka kadar kalsium darah akan mengalami penurunan ${ }^{4}$.

Seiring dengan pertambahan usia, fungsi organ tubuh akan semakin menurun, dimana kemampuan tubuh dalam penyerapan kalsium juga akan menurun. Setelah usia 30-an massa tulang berkurang secara bertahap terutama pada wanita sejalan dengan berkurangnya hormon estrogen yang berperan dalam me njaga keseimbangan kalsium dalam tubuh $^{5}$.

3. Kadar kalsium darah pada wanita menopause berdasarkan lama menopause

Hasil analisis terhadap kadar kalsium darah dari 30 responden diperoleh kadar kalsium darah terendah adalah sebesar $8,0 \mathrm{mg} / \mathrm{dL}$ yang ditemukan pada responden yang memiliki lama waktu menopause 15 tahun dan 16 tahun, sedangkan kadar kalsium tertinggi namun masih dalam batas normal yaitu 10,10 $\mathrm{mg} / \mathrm{dL}$ ditemukan pada responden yang memiliki lama waktu menopause 3 dan 4 tahun. Hasil ini menggambarkan bahwa kadar kalsium darah rendah terjadi pada wanita menopause yang memiliki waktu menopause yang lama.

Semakin lama waktu menopause maka kadar hormon estrogen akan semakin berkurang sehingga kadar kalsium dalam darah juga dapat berkurang. Kadar hormon estrogen yang semakin berkurang akibat waktu menopause yang lama dapat menyebabkan pembongkaran sel tulang lebih banyak daripada pembentukannya sehingga dapat menyebabkan penyakit osteoporosis ${ }^{6}$. Hasil penelitian Pratiwi (2014), di puskesmas pondok betung menunjukkan bahwa dari 42 responden yang telah mengalami menopause, semuanya memiliki hubungan dengan kejadian osteoporosis $^{8}$.

\section{Kadar kalsium darah pada wanita menopause berdasarkan pekerjaan}

Hasil analisis terhadap kadar kalsium darah dari 30 responden diperoleh kadar kalsium darah terendah adalah sebesar $8,0 \mathrm{mg} / \mathrm{dL}$ yang ditemukan pada responden dengan pekerjaan sebagai 73 
Rumah Tangga (IRT) dan pedagang, sedangkan kadar kalsium darah tertinggi namun masih dalam batas normal, yaitu sebesar 10,10 mg/dL ditemukan pada responden dengan pekerjaan sebagai buruh dan petani. Hasil ini menggambarkan bahwa kadar kalsium darah rendah terjadi pada wanita menopause yang memiliki pekerjaan dengan aktivitas yang ringan.

Hasil pemeriksaan kadar kalsium darah normal pada responden dapat disebabkan karena aktivitas fisik yang baik dan teratur. Menurut Maryam (2016), aktivitas fisik berpengaruh baik terhadap absorpsi kalsium. Aktivitas fisik yang baik dan teratur menyebabkan semua hormon dan enzim menjadi aktif sehingga baik penyerapan kalsium maupun fungsi organorgan lain seperti organ reproduksi dapat bekerja dengan baik sehingga dapat mempertahankan dan meningkatkan massa tulang dan mengurangi risiko terkena osteoporosis $^{3}$. Berdasarkan penelitian Minropa (2013), dari 14 responden yang memiliki aktivitas tinggi terdapat 11 responden $(78,6 \%)$ mempunyai risiko negatif osteoporosis ${ }^{4}$.

5. Kadar kalsium darah pada wanita menopause berdasarkan konsumsi susu berkalsium tinggi

Hasil analisis terhadap kadar kalsium darah dari 30 responden diperoleh kadar kalsium darah terendah adalah sebesar $8,0 \mathrm{mg} / \mathrm{dL}$ yang ditemukan pada responden yang tidak pernah mengonsumsi susu berkalsium tinggi dalam 1 bulan terakhir, sedangkan kadar kalsium darah tertinggi namun masih dalam batas normal, yaitu sebesar 10,10 mg/dL ditemukan pada responden yang pernah mengonsumsi susu berkalsium tinggi dalam 1 bulan terakhir dengan frekuensi responden mengonsumsi susu berkalsium tinggi adalah sebanyak 2-3 kali dalam seminggu. Hasil ini menggambarkan bahwa kadar kalsium darah rendah terjadi pada wanita menopause dengan asupan kalsium yang kurang.

Hasil pemeriksaan kadar kalsium darah normal disebabkan karena asupan kalsium yang baik, dari hasil wawancara dapat diketahui bahwa sebagian besar responden yaitu sebanyak $70 \%$ responden pernah mengonsumsi susu berkalsium tinggi dalam 1 bulan terakhir yaitu 2-3 kali dalam seminggu. Susu merupakan sumber kalsium yang cukup besar, satu cangkir susu murni memiliki kandungan kalsium $400 \mathrm{mg}^{6}$. Berdasarkan hasil penelitian Minropa (2013), terdapat $70 \%$ responden memiliki resiko negatif osteoporosis yang ditemukan pada responden dengan asupan kalsium dan fosfor yang cukup ${ }^{4}$.

\section{Kadar kalsium darah pada wanita menopause berdasarkan riwayat}


penyakit (hipoparatiroidisme dan kelainan ginjal)

Hasil analisis terhadap kadar kalsium darah dari 30 responden diperoleh 17\% responden memiliki kadar kalsium darah rendah dan sebagian besar adalah normal yaitu sebanyak $83 \%$ responden. Hasil ini disebabkan karena keadaan responden yang tidak memiliki riwayat penyakit yang dapat menurunkan kadar kalsium darah seperti kelainan ginjal dan hipoparatiroidisme. Apabila ginjal berfungsi dengan baik maka proses penyaringan dan penyerapan kembali kalsium dalam darah tidak akan terganggu, begitu pula dengan proses pengeluaran kalsium melalui urine akan berjalan normal ${ }^{2}$.

Hipoparatiroidisme merupakan suatu keadaan dimana kelenjar paratiroid tidak mensekresikan hormon paratiroid (PTH) dalam jumlah yang cukup sehingga kadar kalsium dalam cairan tubuh akan menurun. Hormon paratiroid berfungsi untuk mempertahankan kadar kalsium di dalam cairan ekstraseluler dengan cara merangsang sintesis $1,25(\mathrm{OH})_{2} \mathrm{D}_{3}$ di ginjal, sehingga absorpsi kalsium di usus meningkat, selain itu hormon PTH juga merangsang formasi tulang ${ }^{9}$.

\section{Simpulan}

Wanita Menopause di Desa Sinabun, Kecamatan Sawan, Kabupaten Buleleng memiliki rata-rata kadar kalsium darah sebesar 9,20 mg/dL, dimana $17 \%$ responden memiliki kadar kalsium darah rendah dan $83 \%$ responden memiliki kadar kalsium darah normal. Kadar kalsium darah rendah ditemukan pada responden kelompok usia $\geq 60$ tahun yaitu sebesar 17\%, pada responden dengan lama menopause $>10$ tahun yaitu sebesar $17 \%$, pada responden yang memiliki pekerjaan sebagai ibu rumah tangga (IRT) sebesar $10 \%$ dan pedagang sebesar $7 \%$, pada responden yang tidak pernah mengonsumsi susu berkalsium tinggi yait sebesar $14 \%$ dan pada responden yang pernah mengonsumsi susu berkalsium tinggi yaitu sebesar 3\%, serta pada responden yang tidak memiliki riwayat penyakit (hipoparatiroidisme dan kelainan ginjal) yaitu sebesar $17 \%$.

\section{Saran}

Perlu dilakukan penelitian lebih lanjut dengan mengontrol faktor-faktor risiko lain yang dapat mempengaruhi kadar kalsium darah, seperti kebiasaan konsumsi minuman beralkohol, kebiasaan merokok dan penyakit lain yang dapat mempengaruhi kadar kalsium darah.

\section{SIMPULAN DAN SARAN}

\section{DAFTAR PUSTAKA}


1. Dewi, M.I.K. 2014. Gambaran Kadar Kalsium Darah pada Wanita Menopause di Banjar Binoh Kaja, Desa Ubung Kaja, kecamatan Denpasar Utara. Denpasar : Politeknik Kesehatan Denpasar.

2. Ganong, W.F. 2008. Buku Ajar Fisiologi Kedokteran. Edisi 22. Jakarta : EGC.

3. Maryam, S. 2016. Gizi Dalam Kesehatan Reproduksi. Jakarta Selatan : Salemba Medika.

4. Minropa, A. 2013. Faktor-Faktor yang Berhubungan dengan Resiko Osteoporosis pada Lansia di Kenagarian Api-Api Wilayah Kerja Puskesmas Pasar Baru Kecamatan Bayang Kabupaten Pesisir Selatan Tahun 2013. tersedia dalam http://journal.mercubaktijaya.ac.id/downlotfil e.php?file=4f.pdf. diakses tanggal 22 September 2016.

5. Noor, Z. 2014. Buku Ajar OSTEOPOROSIS Patofisiologi dan Peran Atom Mineral dalam Manajemen Terapi. Jakarta Selatan : Salemba Medika.

6. Nurrahmani, U. 2012. Stop Osteoporosis. Yogjakarta : Familia.
7. Pusat Data Dan Informasi Kementerian Kesehatan RI. 2015. Data \& Kondisi Penyakit Osteoporosis di Indonesia. tersedia dalam http://www.depkes.go.id/resources/download/ pusdatin/profil-kesehatan-indonesia/profilkesehatan-Indonesia-2015.pdf. diakses tanggal 11 Januari 2017.

8. Pratiwi, R. 2014. Faktor-faktor yang berhubungan dengan kejadian Osteoporosis di puskesmas pondok betung tahun 2014. tersedia dalam http://repository.uinjkt.ac.id/dspace/bitstream/ 123456789/25661/1/ROSI\%20PRATIWI\%20 -\%20fkik.pdf. diakses tanggal 27 Mei 2017.

9. Sudoyo, A. W., B. Setiyohadi, I. Alwi, M. Simadibrata, dan S. Setiati. 2010. Ilmu Penyakit Dalam. Jilid III, Edisi V. Jakarta: Internapublishing..

10. Syahputra, M., E. Suparman., dan H.M.M. Tendean. 2016. Gambaran Kadar Kalsium Wanita Menopause Di Panti Werdha Damai Manado. Jurnal e-Clinic. 4(1) : 426-429. 